Abstracta Iranica Abstracta Iranica

Revue bibliographique pour le domaine irano-aryen

Volume 26 | 2005

Comptes rendus des publications de 2003

\title{
« Hatra. Presentazione del sito ». Topoi 10,1 (2000) [2002], Dossier Hatra, pp. 87-110, 6 figs.
}

\section{Karin Mosig-Walburg}

\section{(2) OpenEdition}

1 Journals

\section{Édition électronique}

URL : http://journals.openedition.org/abstractairanica/3509

DOI : 10.4000/abstractairanica.3509

ISSN : 1961-960X

Éditeur :

CNRS (UMR 7528 Mondes iraniens et indiens), Éditions de l'IFRI

\section{Édition imprimée}

Date de publication : 15 mai 2005

ISSN : 0240-8910

\section{Référence électronique}

Karin Mosig-Walburg, « « Hatra. Presentazione del sito ». Topoi 10,1 (2000) [2002], Dossier Hatra, pp. 87-110, 6 figs. », Abstracta Iranica [En ligne], Volume 26 | 2005, document 174, mis en ligne le 08 décembre 2005, consulté le 25 septembre 2020. URL : http://journals.openedition.org/ abstractairanica/3509; DOI : https://doi.org/10.4000/abstractairanica.3509

Ce document a été généré automatiquement le 25 septembre 2020.

Tous droits réservés 


\section{« Hatra. Presentazione del sito ». Topoi 10,1 (2000) [2002], Dossier Hatra, pp. 87-110, 6 figs.}

\section{Karin Mosig-Walburg}

Description de la position géographique de Hatra, courts renvois à son histoire entre Parthes et Romains, histoire de son exploration scientifique et aperçu des témoignages archéologiques de la ville (fortifications, temples, maisons privées, palais, art figuratif, peinture, graffittis).

\section{INDEX}

Thèmes : 3.2.3. Séleucides, Parthes et Sassanides

\section{AUTEURS}

KARIN MOSIG-WALBURG

Université de Francfort 